\title{
Tax policy, venture capital, and entrepreneurship
}

\author{
Christian Keuschnigg ${ }^{\mathrm{a}, *}$, Soren Bo Nielsen ${ }^{\mathrm{b}}$ \\ ${ }^{a}$ University of St. Gallen (IFF-HSG), CEPR and CESifo, Varnbuelstrasse 19, CH-9000 St. Gallen, \\ Switzerland \\ ${ }^{\mathrm{b}}$ Department of Economics, Copenhagen Business School, EPRU, CEPR and CESifo, \\ Solbjerg Plads 3, DK-2000 Frederiksberg, Denmark
}

\begin{abstract}
The paper studies the effects of tax policy on venture capital activity. Entrepreneurs pursue a single high risk project each but have no own resources. Financiers provide funds, covering investment cost plus an upfront payment, in exchange for a share in the firm. The contract must include incentives to enlist full effort of entrepreneurs. Venture capitalists also assist with valuable business advice to enhance survival chances. The paper develops a general equilibrium framework with a traditional and an entrepreneurial sector and investigates the effects of taxes on the equilibrium level of managerial advice, entrepreneurship and welfare. It considers differential wage and capital income taxes, a comprehensive income tax, progressive taxation as well as investment and output subsidies to the entrepreneurial sector.

(C) 2003 Elsevier Science B.V. All rights reserved.
\end{abstract}

Keywords: Entrepreneurship; Venture capital; Moral hazard; Taxes; Subsidies

JEL classification: D82; G24; H24; H25

\section{Introduction}

Financing early stage businesses involves special problems and is fundamentally different from financing mature and well established companies. Because of lacking collateral and the absence of any past track record, and due to their

\footnotetext{
*Corresponding author. Tel.: +41-71-224-2520; fax: +41-71-224-2670.

E-mail address: christian.keuschnigg@unisg.ch (C. Keuschnigg).
} 
informational advantages, pioneering entrepreneurs often face severe difficulties in convincing banks to finance projects with potentially high returns but high risks as well. Another problem that contains the roots of business failure, is the commercial inexperience of new entrepreneurs. They tend to be equipped with excellent technological expertise but usually lack business experience and managerial training. Venture capital (VC) has come to specialize in financing early stage investment. Venture capitalists (VCs) finance the investment cost but also provide valuable business advice to enhance survival chances of start-up firms. Viewing business formation as a key source of innovation, growth and employment, policy makers often emphasize the need to enhance entrepreneurship and VC activity.'

The traditional literature on entrepreneurship, risk taking and taxation ignores a distinct feature of $\mathrm{VC}$ finance, i.e., the productive contribution of financiers to the success of start-up firms. ${ }^{2}$ The tax literature on adverse selection in investment finance similarly excludes an active role of financiers. ${ }^{3}$ Despite the importance attached to VC by the policy community, a systematic analysis of public policy in this context has largely been neglected. The exceptions are Gordon (1998) and Poterba (1989a,b). Gordon points to the importance of tax avoidance through business ownership as a determinant of entrepreneurship. In this context, he briefly addresses the implications of asymmetric information for the availability of outside equity finance and also studies the role of various tax instruments. Poterba investigates the effects of capital gains taxes on the supply of VC. Neither of them is very specific on the contractual problems in $\mathrm{VC}$ finance. Both abstract from managerial support and tax incentives on this margin. Many business failures, however, result from avoidable management mistakes that originate in the commercial inexperience of entrepreneurs in the early stages of their career. An active role of VCs in providing valuable business advice might be an important factor in raising survival rates of start-up firms. It thus seems interesting to ask which factors determine the incentives to provide advice. Could taxes and other government activity improve upon such incentives and, thereby, boost survival rates by improving the 'quality' of $\mathrm{VC}$ finance?

This paper extends the existing literature on entrepreneurship and taxation in allowing for an active role of financiers and providing an analysis of various tax policy initiatives. We propose a stylized general equilibrium model of entrepreneurship and VC, featuring two sectors: one producing 'traditional' goods and another entrepreneurial sector where an 'innovative' good is produced with an

\footnotetext{
${ }^{1}$ A recent OECD report on Austria, for example, includes a special feature on promoting entrepreneurship, see OECD (1999). Similar issues are also discussed in European Commission (1999).

${ }^{2}$ See, for example, Boadway et al. (1991), Peck (1989), Kihlstrom and Laffont (1983), Mintz (1981), Kanbur (1980) and Buchholz and Konrad (2000) for a recent overview.

${ }^{3}$ See DeMeza and Webb (1987, 1988), Innes (1991), Konrad and Richter (1995), Boadway et al. (1998).
} 
inherently risky technology, and where informational problems loom large. The model conforms well with some important stylized facts of VC finance. ${ }^{4}$ Financiers provide start-up finance in exchange for an equity share. The typical arrangement consists of an upfront payment combined with profit participation. In financing a portfolio of companies, $\mathrm{VC}$ funds are able to diversify risk and could, in principle, fully insure the entrepreneur. Risk diversification, however, is limited by the extent of moral hazard in the relation between entrepreneur and financier. The contract must thus be structured to retain the entrepreneur's full commitment and effort in the face of an incentive problem that results from entrepreneurial effort being non-observable and non-verifiable by an outside investor. While the entrepreneur's effort certainly is critical for the venture to have any positive survival chance at all, the financier also contributes with valuable business advice to further enhance survival rates.

Apart from solving incentive problems with respect to entrepreneurial effort, the $\mathrm{VC}$ contract must be sufficiently generous to attract entrepreneurs in the presence of alternative career opportunities. Agents may either go for a safe worker's salary in the traditional sector or opt for an entrepreneurial career with potentially high rewards but high risk as well. The equilibrium solution with occupational choice splits the population into technologically knowledgeable entrepreneurs, commercially experienced VCs and workers. It endogenously determines the quality of VC finance (i.e., the extent of managerial advice).

To the best of our knowledge, this is the first paper to investigate the consequences of tax policy for the quality of $\mathrm{VC}$ finance and the equilibrium level of start-up entrepreneurship. We study the effects on the amount of VC advice, entrepreneurship, and welfare of a broad range of tax instruments such as differential wage and capital income (dividend or capital gains) taxes, progressive taxation, a subsidy to start-up investment cost and an output subsidy to portfolio companies. The paper now proceeds with presenting the model in Section 2. Section 3 discusses the effects of proportional taxes on the equilibrium level of managerial advice and VC backed start-up investment. Section 4 addresses the welfare implications of policy. Section 5 explores separately the possibility of welfare gains from social insurance by means of progressive taxation. Section 6 summarizes and discusses potential limitations and future research.

\footnotetext{
${ }^{4}$ See Sahlmann (1990), Lerner (1995), Gompers (1995) and Black and Gilson (1998), among others. Gompers and Lerner (1999) provide a systematic account of how the VC industry works.

${ }^{5}$ In focusing on tax incentives, the paper obviously neglects other important aspects of VC finance such as double moral hazard between entrepreneurs and VCs (e.g., Repullo and Suarez (1998) and Schmidt (2000)), or stage financing and convertible debt (e.g., Cornelli and Yosha (1997)). VC firms are also intensively screening projects. The effects of taxes in such context are discussed in the literature on investment with adverse selection, although the intensity of screening is usually not considered.
} 


\section{The Model}

\subsection{Definitions}

\subsubsection{Overview}

The economy consists of two sectors, producing 'traditional' and 'innovative' goods, respectively. A deterministic Ricardian technology is available for production of the traditional good with one unit of labor yielding one unit of output. Choosing the standard good as a numeraire, its price and the wage rate are both equal to one. Innovative goods result from an entrepreneurial activity which is inherently risky and requires a fixed start-up investment on top of the entrepreneur's input. Each entrepreneur pursues exactly one venture that yields one unit of output with probability $p$ and nothing with probability $1-p$. Projects will fail with certainty, however, if entrepreneurs choose not to devote full effort and attention to their venture.

Agents are risk averse and choose to become workers or entrepreneurs. Since entrepreneurs pursue only one project, they face an undiversifiable income risk. No income accrues if the venture fails. In face of this existential risk, entrepreneurial activity can emerge only if financial intermediation provides sufficient insurance. A fixed number $N$ of agents are endowed with unique skills and knowhow that enables them, apart from possibly becoming entrepreneurs or workers, to finance and advise start-up firms. They are called venture capitalists (VCs) or business angels. Assuming project risks to be stochastically independent, these financiers are able to partially insure entrepreneurs by financing a diversified portfolio of projects. The aggregate economy is free of risk.

\subsubsection{Risk, effort and advice}

The survival probability $p$ is assumed to depend on effort which cannot be verified and contracted by an outside investor. Instead of devoting her time and effort to the project, she may prefer to shirk and consume an extra private benefit from shirked effort. An outside investor can hardly observe shirking. We consider only discrete effort choice. Low effort or shirking yields a private benefit while high effort does not. Only high effort implies a positive survival chance $p>0$, while low effort results in business failure for sure, $p=0$. We thus assign a critical role to the entrepreneur. We suppress the effort variable in the probability $p$, knowing that it is positive only if the entrepreneur supplies high effort. In addition to the entrepreneur's effort, we also postulate a productive contribution of the VC consisting of some managerial services $a:^{6}$

$$
p=p(a), \quad p^{\prime}>0>p^{\prime \prime}, \quad p(0)=p_{0}>0, \quad \lim _{a \rightarrow \infty} p(a)<1 .
$$

\footnotetext{
${ }^{6}$ We use $p^{\prime}$ as a short-hand for $\mathrm{d} p / \mathrm{d} a$.
} 


\subsubsection{Taxation of entrepreneur}

Setting up a business requires a fixed start-up investment $K$ which is possibly subsidized at a rate $z$. Investment demand is for traditional goods. A successful project yields one unit of an innovative good which sells for a price $Q$. After investment is completed, the firm yields an expected profit $p Q(1+\sigma)$ where $\sigma$ is an output subsidy to the innovative sector. Since the entrepreneur is assumed to have no own funds, she must finance investment by selling a share $1-s$ of the firm to a financier, or $\mathrm{VC}$. The $\mathrm{VC}$ must thus pay a price $I=b+(1-z) K$ that covers the private cost of investment $(1-z) K$ but also includes an upfront payment. In selling the share, the entrepreneur makes a capital gain $b=I-(1-$ $z) K$ which is subject to a capital income or capital gains tax (CIT) at rate $\tau$. When the firm starts to pay profits $Q(1+\sigma)$, or yields further capital gains from an initial public offering, the entrepreneur again pays a capital income (capital gains) tax on her remaining share. 'Total expected income amounts to

$$
c=(1-\tau)[\operatorname{sp} Q(1+\sigma)+b], \quad I=b+(1-z) K .
$$

\subsubsection{Taxation of $V C$}

The VC bears no risk and calculates with expected profits because she is assumed to hold a diversified portfolio of firms. Entrepreneurs have no funds of their own. To get the firm started, the VC must thus inject equity $I$ which is in exchange for a share $1-s$ of the firm's cash flow. She expects capital gains $(1-s) p Q(1+\sigma)-I$ which are taxed at rate $\tau$. Using (2), her expected, net profit per project is

$$
\begin{aligned}
\pi & =(1-\tau)[(1-s) p Q(1+\sigma)-I-a] \\
& =(1-\tau)[p Q(1+\sigma)-(1-z) K-a]-c .
\end{aligned}
$$

The entrepreneur's expected income $c$ directly subtracts from what may possibly be claimed by the VC. The VC obtains capital income from financing and coaching $n$ start-ups. She spends a variable amount of time $a$ in advising a singly firm. Consulting thus absorbs an of her time in total. ${ }^{8}$ We assume that the VC is self-employed and pays herself a competitive market wage (equal to unity) or management fee that is tax deductible at the VC firm. With complete loss offset, the VC incurs a net loss $(1-\tau)(I+a)$ if the business fails, including the time wasted in advising an unsuccessful firm. At the personal level, the management fee or salary from the VC firm is subject to the general wage tax at rate $t$, giving a total net income from consulting of $a n(1-t)$. Having a time endowment of unity as all other agents, the $\mathrm{VC}$ allocates $1-a n$ of her time to other professional activities which we associate with working in the traditional sector for simplicity, and

\footnotetext{
${ }^{7}$ We abstract from all issues of double taxation at company and personal level.

${ }^{8} \mathrm{We}$ will consider only symmetric situations, giving $\sum_{i=1}^{n} a_{i}=a n$. We will also ignore integer problems in determining the VC's income from $n$ portfolio firms.
} 
obtains a supplementary wage income $(1-a n)(1-t)$. The VC's total net of tax income, consisting of capital gains and wages, therefore amounts to ${ }^{9}$

$$
y^{F}=n \pi+1-t .
$$

\subsubsection{Labor allocation}

The economy is populated with a mass one of agents. A fixed number $N$ of agents have unique managerial skills in advising and financing start-ups although they could give up this activity, if it is unprofitable, for an alternative occupation. We keep this number fixed since a VC's knowhow is highly specialized and difficult to obtain (see Gompers and Lerner (1999, p. 4)). Following an occupational choice decision of a priori identical agents, the rest of the population splits into $L$ workers and $E$ entrepreneurs:

$$
1=L+E+N \text {. }
$$

The production possibilities are traced out by an allocation of labor satisfying the resource constraint. Each entrepreneur starts one firm which produces, if successful, one unit of output. With large numbers, the supply of innovative goods is $S=p(a) E$. Apart from the entrepreneurial input, expected output is enhanced by the VC's managerial support. Each VC finances a portfolio of $E / N=n$ companies. Further, she allocates $1-a n$ of her time to work in the traditional sector. With a unit labor coefficient, supply in the traditional sector thus amounts to $L+(1-$ an) $N=L+N-a E$.

\subsubsection{Income and spending}

Individual income depends on the agent's occupation. A worker obtains a safe salary equal to a wage net of the wage tax $t, y^{L}=1-t .^{10}$ The entrepreneur's income is risky and equal to $c$ in expected value, see (2). The VC obtains a safe income $y^{F}$ as in (4) consisting of profits from the $\mathrm{VC}$ fund plus wages from her managerial activities in the VC fund and elsewhere. Given symmetry within each group, and using $E=n N$, aggregate net income is

$$
Y=\int_{0}^{1} Y^{i} d i=c E+\pi E+(1-t)(N+L) .
$$

\footnotetext{
${ }^{9}$ The VC's profit would be $\pi=(1-\tau)[(1-s) p Q(1+\sigma)-I$, if she chose not to be self-employed, but her wage income would be $(1-a n)(1-t)$ only. Indeed, if $t>\tau$, it would be better not to be self-employed for simple tax reasons while it would make no difference in the absence of taxes. The consulting cost would consist of foregone wages and depend on the wage tax rather than CIT. With this exception, the following analysis remains unaffected. To save space, we consider the case of self-employment only.

${ }^{10}$ Recall that the wage rate is unity by choice of the numeraire.
} 
Agent $i$ consumes quantities $C^{i}$ and $D^{i}$ of traditional and innovative goods, respectively, but is constrained by income $Y^{i},\left(C^{i}+Q D^{i}\right)(1+v) \leq Y^{i}$, or $(C+$ $Q D)(1+v)=Y$ in the aggregate, where $v$ is the rate of a uniform consumption tax.

\subsubsection{Public sector}

The government collects taxes and hands out subsidies. Net revenue is rebated as a consumption subsidy (negative tax). It will become apparent that a proportional consumption subsidy with a uniform rate is neutral and, thus, allows to isolate the allocative effects of other taxes. The government budget constraint is

$$
t(N+L)+\tau[p Q(1+\sigma)-(1-z) K-a] E+v(C+Q D)=\sigma p E Q+z K E .
$$

The wage tax takes not only from the salaries of $L$ workers but also from the professional income of financiers other than their profit income from $\mathrm{VC}$ investing. The capital income (or capital gains) tax is collected from entrepreneurs and VCs. While tax revenue from each project is risky, the government's revenue is deterministic since the law of large numbers consolidates stochastically independent risks.

\subsubsection{Market clearing}

Market clearing in the entrepreneurial sector requires

$$
D=p E .
$$

Walras' Law implies equilibrium in the traditional sector. Start with $Y=(C+$ $Q D)(1+v)$, substitute (3) into (6) and use the result together with (7) and (8) to obtain market clearing in the traditional sector, $C+K E=L+(N-a E)$. Apart from consumption $C$, demand for the traditional good also includes start-up investment $K E$. Supply stems from the output of $L$ workers and the professional activities $(1-a n) N$ of the VCs.

\subsection{Venture capital activity}

\subsubsection{Timing}

VC activity and production in the entrepreneurial sector involves a sequence of events. First, government sets tax policy. Second, the $N$ agents endowed with special management skills decide to establish VC funds with $n$ firms each. ${ }^{11}$ Third, the VCs search for $n$ entrepreneurs, promising to support them with advice $a$. This level of advice determines the quality and reputation of the VC fund. Fourth, the $\mathrm{VC}$ offers a contract to each entrepreneur, claiming a share $1-s$ for a price $I$. The contract must be structured to make entrepreneurship attractive compared to other

\footnotetext{
${ }^{11}$ The number of start-ups in the VC's portfolio is determined in equilibrium by free entry. Kanniainen and Keuschnigg (2000) discuss the individually optimal number of portfolio firms in a risk neutral world.
} 
opportunities (occupational choice) and must provide sufficient incentives for the critical effort of entrepreneurs (no shirking). Fifth, the VC advises the firm. To sustain the quality and reputation of the fund, she sticks to the promised level of advice. The entrepreneur accepts the contract or else opts for a worker's salary. If she accepts, she chooses effort, conditional on the level of VC support and the incentives provided by the contract. Finally, risk is resolved and state-dependent income determined. Knowing income, agents consume and derive welfare.

This timing of events in VC investing is not unique. Repullo and Suarez (1998), Schmidt (2000) and Kanniainen and Keuschnigg (2000) assume instead that the VC cannot commit to the level of advice. ${ }^{12}$ When she chooses advice after the contract is signed, a double moral hazard problem emerges which stresses the role of profit sharing to ensure ex post incentives for VCs. However, our asymmetric view of the VC's and entrepreneur's roles goes quite well with the fact that the entrepreneur pursues a single project only while the VC invests repeatedly in numerous firms. The VC thus has much more to loose in terms of her reputation. Furthermore, the VC's certification role hinges very much on her reputation which helps to attract other investors and convince key suppliers and clients of the firm's viability. In reality, reputation is thus a key factor that determines the VC's effectiveness in providing managerial support. Finally, reputation is worth plain money when the VC divests in launching the firm in an initial public offering. Firms are priced considerably higher at IPO when backed by a well reputed VC. ${ }^{13}$ We may thus reasonably assume that VCs will not put their reputation and effectiveness at risk by deviating, out of a short-sighted profit motive, from the promised level of advice. Nevertheless, it is important to discuss the potential sensitivity of our results with respect to this assumption which we will do in the last section.

\subsubsection{Welfare}

We solve the model by backward induction. Demand derives from utility maximization subject to the budget constraint $\left(C_{i}+Q D_{i}\right)(1+v) \leq Y_{i}$. Given preferences $u=\ln \left(u_{0} \cdot C^{\alpha} D^{1-\alpha}\right)$, where $u_{0}=\alpha^{-\alpha}(1-\alpha)^{-(1-\alpha)}$ for convenience, agents spend

$$
\begin{aligned}
& (1+v) C_{i}=\alpha Y_{i}, \quad(1+v) Q D_{i}=(1-\alpha) Y_{i}, \\
& V_{i}=\ln \left(Y_{i} / P\right), \quad P=(1+v) Q^{1-\alpha} .
\end{aligned}
$$

\footnotetext{
${ }^{12}$ The present paper stresses entrepreneurial risk bearing which, unfortunately, renders the analysis of double moral hazard rather more difficult. The above mentioned authors all assume risk neutrality.

${ }^{13}$ The certification role of VCs and the superior performance of VC backed firms at IPO is well documented by Barry et al. (1990), Megginson and Weiss (1991) and Gompers and Lerner (1999).
} 
Indirect utility $V_{i}$ is concave in real income where $P$ is a price index. The logarithmic specification of utility implies constant relative risk aversion equal to unity.

\subsubsection{Occupational choice and effort}

At this stage, the $\mathrm{VC}$ has offered a share $1-s$ at a price $I$ that yields a capital gain $b$ over the start-up cost $(1-z) K$. The capital gain yields a safe income $b$ in both states of nature. In addition, the entrepreneur retains a share $s$ in the firm, yielding an additional profit income $s Q(1+\sigma)$ if the venture succeeds. The success probability is positive only if the entrepreneur supplies high effort. Even then the firm fails with probability $1-p>0$. After all, start-up entrepreneurship is a highly risky endeavor. If the start-up fails, the entrepreneur is left with her initial gain $b$ but obtains no further dividend or capital gain from an IPO. Assuming that capital gains and dividends are taxed at the same rate $\tau$, we define capital income net of taxes as

$$
\theta \equiv(1-\tau) s Q(1+\sigma), \quad \beta \equiv(1-\tau) b, \quad c=p \theta+\beta .
$$

A hard working entrepreneur faces a positive success probability and expects an income of $c=p(\theta+\beta)+(1-p) \beta$ on average, see (2). She accepts the contract and starts a firm only if the income prospects yield expected utility at least as good as utility from a safe worker's salary $1-t$ net of taxes. This participation constraint (PC) requires the contract to be sufficiently generous. Fig. 1 illustrates. The level of the indifference curve is fixed by the net wage which is a point on the $45^{\circ}$ line: ${ }^{14}$

$$
\begin{array}{ll}
P C: & p \ln (\theta+\beta)+(1-p) \ln (\beta) \geq \ln (1-t), \\
\text { IC }: & p \ln (\theta+\beta)+(1-p) \ln (\beta) \geq \ln (\beta \delta), \quad \delta>1 .
\end{array}
$$

Shirking always leads to business failure and the profit income of a successful start-up never materializes. The entrepreneur is left with a net initial capital gain $\beta$ only but derives an extra, unobserved private benefit, or leisure, with utility value $\ln (\delta), \delta>1$. Her utility from shirking is, thus, $\ln (\beta)+\ln (\delta)=\ln (\beta \delta)$. When the business fails, the $\mathrm{VC}$ derives no revenues at all but incurs a loss of $I$. To protect her revenues, she must prevent avoidable business failure due to shirking. She must cede a sufficiently large profit share to make the entrepreneur participate in the project risk, thereby internalizing the fatal consequences of shirking. The incentive compatibility (IC) condition in (11) thus specifies a $\theta$, and implicitly a profit share $s$, that suffices to prevent shirking for any given safe income $\beta$. The IC

\footnotetext{
${ }^{14}$ Since utility is $\ln \left(Y_{i} / P\right)$, the $\mathrm{PC}$ actually reads $p \ln [(\theta+\beta) / P]+(1-p) \ln [\beta / P] \geq \ln [(1-t) / P]$. Due to the logarithmic specification of utility, the price index cancels on each side.
} 


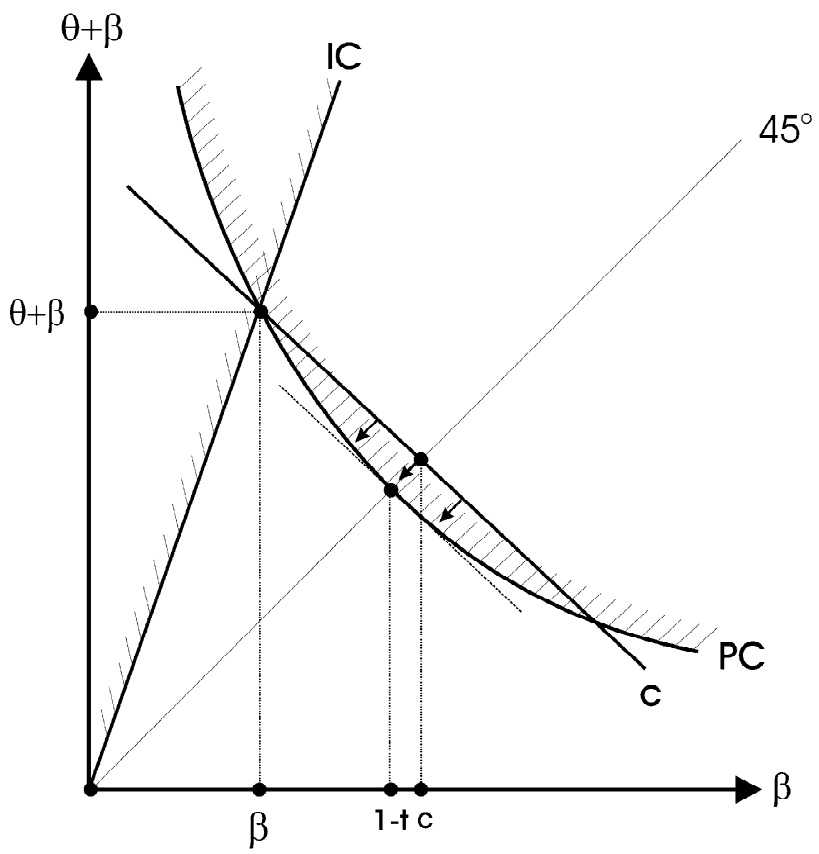

Fig. 1. Contract.

is fulfilled if expected utility from supplying high effort is no lower than utility from shirking. By a simple transformation, we may write the IC condition in (11) as $\theta+\beta=\beta \delta^{1 / p}$ which is drawn as a ray through the origin in Fig. 1 with slope steeper than the $45^{\circ}$ line. As $\delta \rightarrow 1$, the IC condition rotates until it coincides with the $45^{\circ}$ line and the shirking problem disappears.

\subsubsection{Incentive contract}

The VC proposes a contract that maximizes her own profits $\pi$ in (3) subject to the requirements stated in (11). Given probability $p(a)$, profit maximization is equivalent to minimizing the cost $c=p \theta+\beta$ of compensating entrepreneurs as is apparent from (3). With prices and taxes taken as given, the choice of a share $s$ and a net gain $b$ is equivalent to choosing $\theta$ and $\beta$. Since the VC is fully diversified and bears no risk, she is only interested in minimizing expected cost but is otherwise indifferent between safe or risky compensation, i.e., the cost line in Fig. 1 is linear with slope $-(1-p) / p$. Cost is minimized where the two constraints intersect. The solution fixes the entrepreneur's safe income $\beta$ which 
derives from a price $I$ in excess of investment cost $(1-z) K$, and her extra income $\theta$ in the good state which stems from a profit share $s .^{15}$

The solution specifies a cost of contract that exceeds a safe net salary $1-t$ by a risk premium. Risk bearing is dictated by the incentive compatibility condition. If it were not required for incentive reasons, the VC could save cost by reducing the entrepreneur's profit share and risk. If the incentive constraint were slack which would automatically be the case if private benefits of shirking were absent $(\delta=1)$, the optimal solution would be full insurance with $\beta=1-t$ and $\theta=0$, making the participation constraint and the cost line tangent in Fig. 1. If the incentive problem becomes severe, the VC must shift some risk to the entrepreneur. Since risk bearing must be compensated in terms of a risk premium over the utility equivalent safe income $1-t$, the required incentives inflate the expected cost of the contract. Fig. 1 illustrates. Moving away from full insurance along the PC, the reduction of the safe income $\beta$ must be compensated by ever higher profit shares such that expected income exceeds the safe alternative by a premium to reward for risk bearing. For an analytical solution, we get $\ln (1-t)=\ln (\beta \delta)$ from the intersection, or $\beta \delta=1-t$. The PC then gives $1-t=(\theta+\beta)^{p} \beta^{1-p}$, or

$$
\theta=\beta\left(\delta^{1 / p}-1\right), \quad \beta=\frac{1-t}{\delta}, \quad \frac{\mathrm{d} \theta}{\mathrm{d} t}=\frac{-\theta}{\beta \delta}=\frac{-\theta}{1-t}<0
$$

and $\mathrm{d} \theta / \mathrm{d} \tau=\mathrm{d} \theta / \mathrm{d} \sigma=\mathrm{d} \theta / \mathrm{d} z=0$. We note some immediate implications for tax incidence. The net capital gain $\beta$ is tied to foregone wages $1-t$ and to the disutility of effort, or foregone leisure value $\delta$, but is independent of the CIT rate $\tau$. For a given survival rate $p$, the entrepreneur's profit income $\theta=s(1-\tau) Q(1+\sigma)$ depends only on the net gain $\beta=(1-t) / \delta$. Since both are independent of the CIT, this tax is fully shifted to the VC by inflating the purchase price $I$, on account of $b=\beta /(1-\tau)$, and the profit share $s$, leaving the entrepreneur's income in both states unchanged. Similarly, the output subsidy $\sigma$ fully accrues to the VC while the

\footnotetext{
${ }^{15}$ While the equity interpretation is more natural in this context, our simple model also allows to interpret the solution as a debt contract by relabeling $I=b+(1-z) K$ as debt and $R \equiv(1-s) Q(1+\sigma)$ as debt repayment. Due to risk aversion, the entrepreneur must receive a minimum safe income $b$. If it is provided by an upfront payment out of the firm's expected profits, the entrepreneur is subject to CIT and receives $\beta=(1-\tau) b$. Nothing is repaid in the bad state when the firm defaults. In the good state, prepaid profit $b$ reduces the entrepreneur's remaining profits. Defining $\theta=(1-\tau)[Q(1+\sigma)-R]$, expected income $c=p \theta+\beta$ is determined exactly the same way as in our equity formulation, see Fig. 1. The VC's expected profit is $\pi=(1-\tau)(p R-a-I)$. Using the definitions of $\theta, I$ and $c$ yields $\pi=(1-\tau)[p Q(1+\sigma)-a-(1-z) K]-c$ as in (3). In our simple model, debt and equity finance are actually equivalent and equally useful to overcome the incentive problem. In an extended setting of double sided moral hazard, however, the optimal contract would definitely call for equity finance, or the use of equity-like forms of debt such as convertible debt.
} 
entrepreneur is able to capture not even part of it. In contrast, a higher wage tax reduces the entrepreneur's alternative income and thus allows the VC, ceteris paribus, to retain participation and effort in spite of acquiring a higher share $1-s$ at a lower price. The burden of the wage tax lies as much with entrepreneurs as with workers. In equilibrium, however, the survival rate is endogenously determined which will then affect the described pattern of tax shifting.

The contract cost that the VC must incur to attract an entrepreneur determines her residual income and willingness to invest. It depends on taxes. In raising survival chances $p(a)$ through more intensive advice, the VC herself may control the cost:

Proposition 1 (Cost of Contract). The cost $c(p ; t)=p \theta+\beta$ of incentive compatible compensation of the entrepreneur satisfies

$$
c^{\prime} \equiv \frac{\mathrm{d} c}{\mathrm{~d} p}<0, \quad c^{\prime \prime} \equiv \frac{\mathrm{d}^{2} c}{\mathrm{~d} p^{2}}>0 ; \quad \frac{\mathrm{d} c}{\mathrm{~d} t}=-\frac{c}{1-t}<0 .
$$

It declines with the wage tax but is independent of other policy parameters.

Proof. See Appendix A. For policy effects, differentiate $c$ and make use of (12).

There are two offsetting influences of $p$ on cost. On the one hand, a higher survival rate raises cost since high income must be paid with higher probability. On the other hand, when project risk declines, the principal may ensure participation of the entrepreneur with a smaller risk premium. The VC is therefore able to squeeze the entrepreneur's profit share in the successful state, $\partial \theta / \partial p<0$. The second effect dominates and marginal cost falls. Furthermore, the cost function is unambiguously convex in the survival rate. Since the wage tax makes the alternative career option less attractive, the VC succeeds to save contract cost in buying a larger share at a lower price. The entrepreneur's expected income correspondingly falls, along with her alternative wage income. Note finally that contract cost is completely independent of other subsidies or taxes. The CIT is fully shifted to the VC and has no bearing on the entrepreneur's expected income. The output subsidy $\sigma$ boosts the company's cash flow in case of success but the VC simply cuts the entrepreneur's profit share and appropriates all of it. The investment tax credit similarly benefits the $\mathrm{VC}$ by reducing the price $I=b+(1-$ $z) K$ since the entrepreneur's net gain $\beta=(1-\tau) b$ is tied to net wages and effort cost only.

\subsubsection{Managerial advice}

Only successfully launched businesses eventually contribute to the VC's revenues. According to (1), however, VCs may themselves enhance survival 
chances of portfolio companies and strengthen their revenues by giving business advice. In raising the survival rate, more advice also allows to squeeze the entrepreneur's risk premium over safe wage income by making income less risky. The venture may thus be obtained at lower cost. Managerial advice, however, is time intensive and costly. The profit maximizing level of advice is most easily analyzed in rewriting (3) as

$$
\begin{aligned}
& \pi=\max _{a} p(a)[(1-\tau) Q(1+\sigma)-m], \\
& m \equiv \frac{c[p(a) ; t]+(1-\tau)[a+(1-z) K]}{p(a)} .
\end{aligned}
$$

We refer to $m$ as cost to market which is the expected cost incurred in order to produce one unit of the innovative good. On average, one must start $1 / p$ projects to accomplish this. Apart from savings in contract cost, an increase in the survival rate now reduces cost to market because a smaller number of projects needs to be started for each successful one. The necessary and sufficient conditions for the VC's advisory activity are, thus, ${ }^{16}$

$$
\begin{aligned}
\tau^{\prime} & =p^{\prime}\{(1-\tau) Q(1+\sigma)-m\}-p m^{\prime} \\
& =p^{\prime}\left[(1-\tau) Q(1+\sigma)-c^{\prime}\right]-(1-\tau)=0 \\
\tau^{\prime \prime} & =p^{\prime \prime}\{(1-\tau) Q(1+\sigma)-m\}-2 p^{\prime} m^{\prime}-p m^{\prime \prime} \\
& =p^{\prime \prime}\left[(1-\tau) Q(1+\sigma)-c^{\prime}\right]-p^{\prime} c^{\prime \prime}<0
\end{aligned}
$$

The second-order condition is fulfilled by the curvature properties of $p(a)$ and $c(p ; t)$.

\subsection{Equilibrium}

\subsubsection{Zero profits and managerial advice}

As long as they make profits, VCs attract ever more entrepreneurs to start up new businesses. Increasing supply will eventually exhaust profit opportunities in the entrepreneurial sector. In equilibrium with free entry, the price of innovative goods adjusts to eliminate profits in VC investing, $\pi=0$. Competitive VCs are thus able to earn an income $y^{F}=1-t$ no higher than what they could earn in pursuing a professional career in industry. The condition that profits be nonnegative, is the participation constraint of the VC. By (13), the competitive price is

$$
(1-\tau) Q(1+\sigma)=m .
$$

The competitive producer price net of the CIT must be equal to the cost $m$ of bringing a venture to the market. The intensity of advice and the equilibrium price are solved recursively. Imposing (15) on the optimality condition (14) gives

\footnotetext{
${ }^{16} p^{\prime}$ and $\pi^{\prime}$ denote derivatives with respect to $a$, while $c^{\prime}$ denotes the derivative w.r.t. $p$.
} 


$$
\pi^{\prime}=-p m^{\prime}=p^{\prime}\left(m-c^{\prime}\right)-(1-\tau)=0
$$

where $c$ depends on $a$ only via its effect on $p$. This equation autonomously determines advice. In equilibrium, the VC's marginal benefit of advice is ( $m-$ $\left.c^{\prime}\right) p^{\prime}$. Managerial support boosts survival rates which directly reduces cost to market, and also indirectly since lower risk allows to cut the profit share and to save part of the entrepreneur's risk premium. The VC incurs a marginal cost of advice equal to $1-\tau$. Once advice is known, $p, c$, and $m$ are determined which, in turn, fixes the demand price $Q$ in (15).

\subsubsection{Number of entrepreneurs}

Imposing labor market clearing and budget constraints, we solve for the number of entrepreneurs that equilibrate the market for innovative goods. Walras' Law implies market clearing for standard goods. Given neutrality of the consumption tax, equilibrium is independent of its rate. We start with the observation in (9) that agents spend a fixed share of income on innovative goods, $Q D=(1-\alpha) Y /(1+$ $v)=(1-\alpha) Y^{G}$ where $Y^{G} \equiv Y /(1+v)=C+Q D=Y-v(C+Q D)$ denotes gross factor income. ${ }^{17}$ Substituting $c+\pi$ from (3) into (6), using the government budget constraint (7) and finally the resource constraint (4), we obtain

$$
Y^{G}=Y-v Y^{G}=1+(p Q-K-a-1) E .
$$

Equate supply and demand in the entrepreneurial sector, $p E=(1-\alpha) Y^{G} / Q$. Note that managerial advice is autonomously fixed in zero profit equilibrium by (16) and thereby determines survival probability $p$, contract cost $c$ and cost to market $m$ independently from the rest of the model. Fig. 2 illustrates the solution for the untaxed equilibrium with the number of entrepreneurs being the equilibrating variable. In this case, gross income is $Y^{G}=1+(c-1) E$. A part $(1-\alpha) / Q$ of demand is autonomous but the rest increases with $E$ for the simple reason that average income of entrepreneurs exceeds wages by a risk premium $c-1$. The demand schedule is flatter than the supply curve whence the equilibrium number of entrepreneurs is smaller than unity. By (13) and (15), $p Q=p m=c+a+K$. Equating demand and supply thus yields $E=(1-\alpha) /(1-\alpha+a+K+\alpha c)<1$. By the same steps, entrepreneurship in the taxed equilibrium is given by

$$
\begin{aligned}
& 1-\alpha=E \cdot \Omega, \quad \Omega \equiv(1-\alpha)(1+a+K)+\alpha p Q \\
& Q=\frac{m}{(1-\tau)(1+\sigma)} .
\end{aligned}
$$

\footnotetext{
${ }^{17}$ To rebate tax revenues, the government gives a consumption subsidy, i.e., $v<0$. A consumption tax is charged only when an output or investment subsidy must be financed.
} 


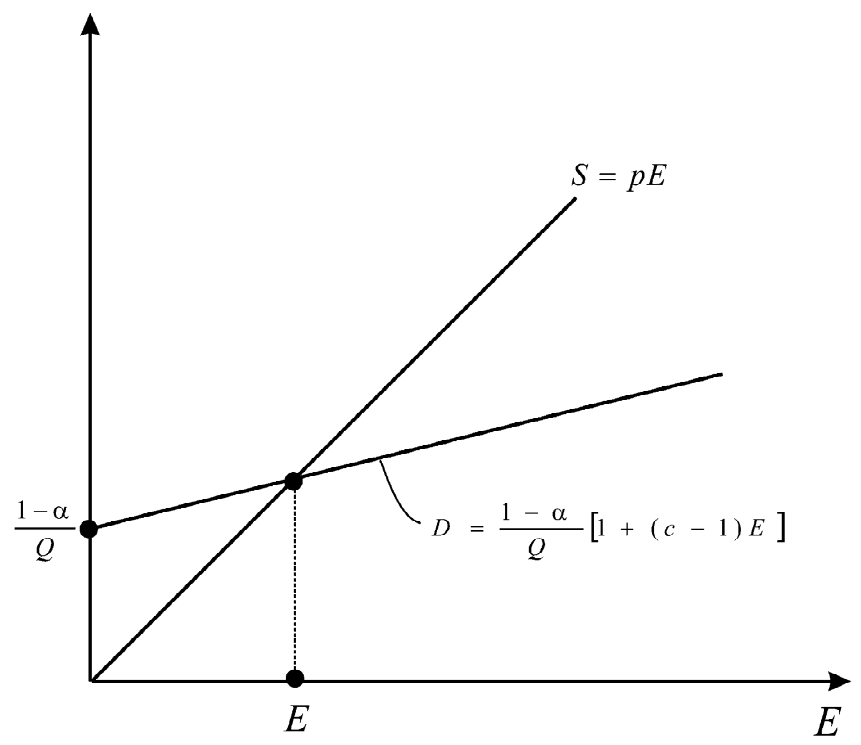

Fig. 2. Number of entrepreneurs.

\section{Entrepreneurship}

\subsection{Cost to market}

The recursive structure greatly simplifies policy analysis. Cost to market and advice are solved autonomously. (16) implies $m^{\prime}=0$ which is also the condition for minimum cost $m=\min _{a}(c(p, t)+(1-\tau)[a+(1-z) K]) / p$. Profit maximization combined with free entry is, thus, equivalent to cost minimization and yields the same level of advice. ${ }^{18}$ Applying the envelope theorem to cost minimization and using Proposition 1 gives

$$
\begin{aligned}
\frac{\mathrm{d} m}{\mathrm{~d} t} & =\frac{-c}{(1-t) p}<0, \quad \frac{\mathrm{d} m}{\mathrm{~d} \tau}=\frac{-[a+(1-z) K]}{p}<0, \\
\frac{d m}{d z} & =\frac{-(1-\tau) K}{p}<0,
\end{aligned}
$$

and $\mathrm{d} m / \mathrm{d} \sigma=0$. The wage tax erodes the entrepreneur's compensation since it reduces her alternative income. The tax thus reduces cost to market which feeds into a lower price of innovative goods. Because investment and consulting costs

\footnotetext{
${ }^{18}$ Imposing zero profits on (16), the necessary and sufficient conditions of the two problems are related according to $\pi^{\prime}=-p m^{\prime}=0$ and $\pi^{\prime \prime}=-p m^{\prime \prime}<0$. The cost function $m$ is convex.
} 
are deductible, the CIT effectively subsidizes these items and reduces cost to market as well. ${ }^{19}$ An investment subsidy $z$ has essentially the same effect. An output subsidy is unable to affect cost to market and producer prices. It is fully passed on to consumers.

\subsection{Managerial advice}

VCs not only provide funds but also supply valuable business advice. Do taxes impair incentives to advise? Henceforth, we use $r$ to denote a comprehensive income tax, i.e., $r=t=\tau$ and $z=0$. The investment subsidy is set to zero because tax deductibility of investment spending already subsidizes the private investment cost. Condition (16) implicitly determines consulting when competition eliminates profits in VC finance.

Proposition 2 (Managerial Advice). In equilibrium with free entry, the intensity of managerial advice increases with a higher capital income tax while a higher investment subsidy and a higher wage tax discourage advice. An output subsidy and a comprehensive income tax $(t=\tau=r$ and $z=0)$ are neutral:

$$
\frac{\mathrm{d} a}{\mathrm{~d} \tau}>0, \quad \frac{\mathrm{d} a}{\mathrm{~d} t}<0, \quad \frac{\mathrm{d} a}{\mathrm{~d} z}<0, \quad \frac{\mathrm{d} a}{\mathrm{~d} r}=\frac{\mathrm{d} a}{\mathrm{~d} \sigma}=0
$$

Proof. Take the differential of (16) and make use of (B.2) in Appendix B,

$$
\pi^{\prime \prime} \mathrm{d} a=\frac{c / p-c^{\prime}}{1-t} p^{\prime} \mathrm{d} t-\frac{c / p-c^{\prime}}{m-c^{\prime}} \mathrm{d} \tau+\frac{(1-\tau) K}{p} p^{\prime} \mathrm{d} z
$$

The output subsidy does not affect the optimality condition. For the comprehensive income tax, see (B.3).

Optimal advice balances marginal benefit $\left(m-c^{\prime}\right) p^{\prime}$ with marginal cost $1-\tau$ of consulting. The marginal benefit derives from a higher survival rate which saves start-up costs 2-fold: fewer projects need to be started for each successful one, and the entrepreneur's risk premium can be reduced. The CIT seemingly holds ambiguous incentives for advice because it affects both sides of the margin. On the one hand, it reduces the marginal benefit by $p^{\prime} \partial m / \partial \tau$. When the price equal to start-up cost declines due to the implicit tax subsidy associated with a higher CIT rate, then less is gained by raising the survival rate and further reducing the start-up cost. On the other hand, a higher CIT raises the implicit tax subsidy from deductibility of consulting costs and thereby reduces the marginal cost of advice by $-\mathrm{d} \tau$. As (B.2) shows, the second effect dominates. By encouraging advice, the

\footnotetext{
${ }^{19}$ If the VC were not self-employed, the opportunity cost of consulting would be $(1-t) a$. Then the consulting cost would be reduced by the wage tax rather than the CIT as we noted in discussing (4).
} 
CIT strengthens survival chances of firms. The other policy variables operate only via their effect on marginal benefits. The wage tax, for example, reduces start-up cost since it allows to cut the entrepreneur's compensation. The investment subsidy directly reduces cost. When the competitive project value equal to start-up cost becomes smaller, less is gained by advising more intensively. A uniform income tax avoids interfering with incentives since it affects marginal benefits and costs of advice proportionately.

\subsection{Entrepreneurship}

With an endogenous survival rate, the number of entrepreneurs $E$ willing to start up new firms is no longer proportional to and must be distinguished from the number of successful projects $p E$. How then is tax policy affecting entrepreneurship and supply in the innovative sector? The quality of VC finance determines risk and thereby affects agents' willingness to opt for an entrepreneurial career. Are tax incentives for advice in line with the tax effects on occupational choice? To build intuition, consider first the market for innovative goods in the untaxed equilibrium which is $p(a) E=(1-\alpha)[1+(c-1) E] / m$ with $Q=m$ by the zero profit condition. In holding $a$ constant, we identify some direct effects of taxes on the demand side. For a given number of entrepreneurs, taxes contribute to aggregate income and boost demand if they raise the risk premium, i.e., the income differential, of entrepreneurs. This income effect is enhanced by a price effect if taxes reduce cost to market and thus allow for a lower demand price. To eliminate excess demand, the number of entrepreneurs must increase. The indirect effect of taxes works through incentives for managerial advice. More advice boosts survival chances and adds to supply when a larger fraction of projects succeeds. In reducing risk, advice squeezes the income premium of entrepreneurs and erodes demand. Note also that a marginal increase in advice fails to affect the output price since $m^{\prime}=0$. If taxes stimulate advice, they contribute to excess supply of innovative goods. The number of entrepreneurs must decline to restore equilibrium. With these transmission channels in mind, we consider how policy affects entrepreneurship and industry supply.

Proposition 3 (Entrepreneurship). A wage tax, an investment subsidy and an output subsidy raise the number of entrepreneurs and boost industry supply. The CIT works in the opposite direction. A comprehensive income tax with full loss offset is neutral.

Proof. Take the differential of (17) and use $m^{\prime}=0$ from (16) to get

$$
\begin{array}{ll}
(a)=-\frac{E^{2}}{1-\alpha}[\alpha p \cdot \mathrm{d} Q+\Phi \cdot \mathrm{d} a], & \Phi \equiv 1-\alpha+\alpha Q p^{\prime}>0, \\
(b)=-\frac{E}{1-\alpha}\left[\alpha p^{2} E \cdot \mathrm{d} Q+p^{\prime} \Psi \cdot \mathrm{d} a\right], & \Psi \equiv p E \Phi / p^{\prime}-(1-\alpha)>0 .
\end{array}
$$


The sign of $\Psi$ is not obvious. Write $\Psi=(1-\alpha) p E / p^{\prime}+\alpha p E Q-(1-\alpha)$. Replace $p^{\prime}$ by (16), use (15) and rearrange, $\Psi=p E Q-(1-\alpha)+(1-\alpha) p E\left[Q \sigma-c^{\prime} /(1-\right.$ $\tau)]$. Eq. (17) helps to sign $\Psi$. Expand $\Omega$ such that $\Omega=p Q-(1-\alpha)[p Q-(1+$ $a+K)]$. Then, (17) implies $E p Q>1-\alpha \Leftrightarrow[p Q-(1+a+K)]>0$. The condition holds in the untaxed equilibrium where $p Q=p m=c+a+K$. In this case, $p Q-(1+a+K)=c-1>0$ is equal to the risk premium. By continuity, the condition is at least satisfied when tax and subsidy rates are not too large. With a uniform income tax $(t=\tau=r>0$ and $\sigma=z=0)$, the condition is again related to the entrepreneur's risk premium, $p Q-(1+a+K)=(c-(1-r)) /(1-r)>0$, and is satisfied even for large taxes. With $1-\alpha<E p Q$ established, the first two terms in $\Psi$ sum up positively and the third one is positive as well which establishes the sign $\Psi>0$. To complete the proof, use $Q=m /((1-\tau)(1+\sigma))$ and refer to Proposition 2 and (18) to evaluate (19) for each policy instrument.

\subsubsection{Output subsidy}

In zero profit equilibrium, an output subsidy $\sigma$ avoids distorting incentives for advice. It affects neither survival chances nor cost to market. In subsidizing consumer prices, it boosts demand for innovative goods and, thereby, encourages entrepreneurship and aggregate supply. With $a$ and $p(a)$ fixed, supply increases in proportion with the number of entrepreneurs who start a firm.

\subsubsection{Capital income tax}

The CIT directly cuts into VC revenues but also reduces cost to market in (18) because it provides a tax subsidy on investment and consulting costs which are deductible from the tax base. As a net effect, the tax destroys profits. Competition forces part of the financiers to leave the industry. As fewer projects get funded, the entrepreneurial sector shrinks. The market price of innovative goods must increase until the remaining VC firms are able break even again. From (15) and (18), the price in free entry equilibrium increases by

$$
\frac{\mathrm{d} Q}{\mathrm{~d} \tau}=\frac{Q}{m} \frac{\mathrm{d} m}{\mathrm{~d} \tau}+\frac{Q}{1-\tau}=\frac{Q c}{(1-\tau) m p}>0
$$

If the CIT had no effect on the intensity of advice and, in turn, on the success rate, industry supply would fall in proportion with the number of entrepreneurs. The second term in (19) derives from the fact that the CIT strengthens the incentives of VCs to provide managerial advice, see Proposition 2. This favorable supply effect works like an increase in productivity. As a larger fraction of start-ups turns out successful on account of more intensive coaching, fewer projects need to be started to accommodate a given level of demand. The negative effect on entrepreneurship gets reinforced. The positive effect on advice thus has two offsetting consequences for the supply $p E$ of innovative goods. It raises the number of start-ups but makes 
a smaller fraction of them succeed. On account of $\Psi>0$, the net effect of advice is to strengthen supply.

\subsubsection{Investment subsidy}

An increase in the investment subsidy leads to a rise in both the number of entrepreneurs and the number of successful projects. It lowers cost to market of innovative goods, see (18), which expands supply and attracts additional entrepreneurs. In discouraging VC advice, see Proposition 2, the subsidy reinforces the number of start-ups, although at an increased rate of business failure. Despite of this detrimental risk effect, the subsidy also reinforces the expansion of the entrepreneurial sector. $^{20}$

\subsubsection{Wage tax}

In making the entrepreneur's alternative opportunities less attractive, the wage tax allows to cut their compensation. Competitive VCs will seize the profit opportunities from reduced cost to market and fund more projects until the ensuing price erosion restores zero profits, see (18) and (15). Entrepreneurship and industry supply expand as noted in (19). The wage tax also holds weaker incentives for advice as noted in Proposition 2. Hence, more entrepreneurs start up firms but entrepreneurship becomes riskier, resulting in increased rates of business failure as the quality of VC finance declines.

\subsubsection{Uniform income tax}

A uniform income tax features common rates for wage and capital income (capital gains) taxation, $t=\tau=r$, and it sets the investment subsidy $z=0$ since investment cost is tax deductible already. A uniform tax was shown to be neutral with respect to advice. It turns out that this broad-based tax with full loss offset neither affects entrepreneurship nor the supply of innovative goods. In (19), the direct effect of the tax would enter through $Q=m /(1-r)$ but the tax factor cancels out since all terms in $m$ including $\theta$ as given in (12) are proportional to $1-r^{21}$ Since this tax neither affects advice nor the goods price $Q$, it remains completely neutral.

\footnotetext{
${ }^{20}$ The working paper version (Keuschnigg and Nielsen, 2000) also considered the consequences of restricting full loss offset in taxing VC funds. Such a measure raises cost to market and competitive output price and, via this effect, discourages entrepreneurship and industry output, much like the CIT. Managerial advice is affected ambiguously, however, introducing also a slight ambiguity in the equilibrium effects on entrepreneurship and output.

${ }^{21}$ By $(18), \mathrm{d} m / \mathrm{d} r=\mathrm{d} m / \mathrm{d} t+\mathrm{d} m / \mathrm{d} \tau=-m /(1-r)$ which implies $\mathrm{d} Q / \mathrm{d} r=0$.
} 


\section{Welfare}

Tax policy affects the incentives of VCs to advise entrepreneurs and thereby influences the survival rates of start-up businesses. It also affects the propensity of households to opt for an entrepreneurial career. What are the normative implications from a welfare theoretic point of view? The main complication compared to a standard competitive economy is the presence of asymmetric information in the relation between entrepreneurs and financiers. To avoid moral hazard and to retain survival chances of start-up ventures, the financial contract must be arranged to provide entrepreneurs with sufficient incentives. For this reason, entrepreneurs must bear risk via profit participation even though full diversification would be possible in principle. In the presence of unconsolidated risk, taxation could provide further insurance. It is expected, however, that further diversification is counterproductive since it conflicts with private arrangements to contain moral hazard. We now proceed with an explicit welfare analysis to check this conjecture.

We analyze (ex ante) welfare of agents prior to occupational choice. ${ }^{22}$ Given a price index $P=(1+v) Q^{1-\alpha}$, an agent with real income $Y_{i} / P$ derives utility $V_{i}=\ln \left(Y_{i} / P\right)$, see (9). In equilibrium, expected utility from entrepreneurship is exactly matched by utility from a safe job in manufacturing. The participation constraint holds with equality. Therefore, utility $V_{i}$ of a worker which depends on the after tax real wage $(1-t) / P$, is a complete welfare measure. ${ }^{23}$ The marginal welfare effect is then $\mathrm{d} V=-\mathrm{d} t /(1-t)-\mathrm{d} v /(1+v)-(1-\alpha) \mathrm{d} Q / Q$. For the rest of this section, we start from an untaxed position and derive the marginal welfare effects of introducing small taxes from zero. This way, we avoid complicated tax base effects that would identify the excess burden of taxes. With small taxes, the excess burden is zero to the first order. The remaining welfare effect must then be due to other distortions if there are any. Replacing the term $1-\alpha$ by $(1-\alpha) Y / Y=$ $p E Q / Y$ after making use of (9) and (8), we then have

$$
\mathrm{d} V=-\mathrm{d} t-\mathrm{d} v-\frac{p E}{Y} \mathrm{~d} Q .
$$

Welfare depends on the real wage net of taxes. Tax policy thus affects welfare via three channels: (i) the after-tax wage; (ii) the consumption tax; and (iii) the price of innovative goods. The wage tax determines (i) while (ii) and (iii) reflect the price index. As indicated in (18), tax policy affects the cost to market $m$ and,

\footnotetext{
${ }^{22}$ Boadway et al. (1991) provide a welfare analysis in several models of occupational choice.

${ }^{23}$ This ex ante welfare measure corresponds to a social welfare function which adds up ex post utility of different agents. The population splits into $N+L=1-E$ workers and financiers with safe income, and $E$ entrepreneurs of whom $p E$ are successful and $(1-p) E$ fail. Given net income $Y_{i} \in\{1-t, \theta+$ $\beta, \beta\}$, social welfare is $V=(1-E) \cdot \ln ((1-t) / P)+p E \cdot \ln ((\theta+\beta) / P)+(1-p) E \cdot \ln (\beta / P)$. Since the participation constraint holds with equality, $p \ln ((\theta+\beta) / P)+(1-p) \ln (\beta / P)=\ln ((1-t) / P)$, social welfare amounts to $V=\ln ((1-t) / P)$.
} 
thereby, the competitive price $Q$ that results from free entry as in (15). In particular, the welfare evaluation of taxes must take account of the fact that revenues are rebated by means of a consumption subsidy.

Proposition 4 (Welfare). Using a proportional consumption tax or subsidy to balance the budget, and starting from an untaxed equilibrium, the welfare effects from a small wage tax, CIT, and small output and investment subsidies are zero.

Proof. As a first step in evaluating (21), we compute the differential of the government budget (7) to obtain the adjustment in the consumption subsidy,

$$
Y \mathrm{~d} v=-(1-E) \mathrm{d} t-c E \mathrm{~d} \tau+K E \mathrm{~d} z+p E Q \mathrm{~d} \sigma .
$$

By way of (5), the wage tax base is $L+N=1-E$. Using (15), i.e., $Q=m$, together with (13), the CIT base is $p Q-a-K=c$. Turning to the price effect, we have $\mathrm{d} Q=Q \mathrm{~d} \tau-Q \mathrm{~d} \sigma+\mathrm{d} m$ by (15). Upon substituting (18) and using $Q=m$,

$$
\mathrm{d} Q=\frac{c}{p} \mathrm{~d} \tau-\frac{c}{p} \mathrm{~d} t-Q \mathrm{~d} \sigma-\frac{K}{p} \mathrm{~d} z
$$

Substituting this together with (22) into (21), and noting that $Y=1+(c-1) E$ in the untaxed equilibrium, we find $\mathrm{d} V=0$.

Consider, for example, a small wage tax. It generates revenues $Y \mathrm{~d} v=-(1-$ $E) \mathrm{d} t$. It also reduces cost to market which is passed to consumers in terms of lower prices, $Q=m$ gives $\mathrm{d} Q=-(c / p) \mathrm{d} t$ by (18). Substituting into the welfare differential in (21), and using $Y=1+(c-1) E$, we find $\mathrm{d} V / \mathrm{d} t=0$. It turns out that the subsidy to consumption plus the competitive price reduction result in a real income gain that just suffices to compensate for the loss of income on account of the wage tax. Although the wage tax boosts business start-ups and the supply of innovative goods but impairs VC advice, it fails to raise welfare at the margin. The same holds for the CIT and for the output and investment subsidy. ${ }^{24}$ None of the private decisions in $\mathrm{VC}$ investing and start-up entrepreneurship are distorted.

\section{Progressive taxation}

In discussing the major taxes being relevant for start-up entrepreneurship, we have assumed that the government uses revenues to pay a proportional consumption subsidy. Since the consumption tax or subsidy takes and gives in proportion to each agent's income, it avoids redistribution. We now relax this assumption and

\footnotetext{
${ }^{24}$ Marginally restricting full loss offset of a uniform income tax similarly is devoid of welfare effects as we demonstrated in the working paper version (see Keuschnigg and Nielsen (2000)).
} 
turn to a redistributive policy that levies a proportional (consumption) tax in order to finance a uniform per capita transfer. This scenario mimics an indirectly progressive tax. Obviously, such transfers are relatively more important in case of failure when the entrepreneur is left with a modest income only, as compared to the exceptionally high income generated by a successful start-up. Such transfers thus provide welcome insurance to entrepreneurs. However, risk bearing and ex post income inequality is required to contain moral hazard. It will be important to investigate how a redistributive tax transfer scheme interacts with the financial arrangements in $\mathrm{VC}$ investing.

Proposition 5 (Progressive Taxation). A redistributive tax transfer scheme (uniform transfers financed with a proportional consumption tax) raises cost to market and advice and, thereby, restricts entrepreneurship and industry output. Starting from an untaxed position, the first order welfare effect is zero.

Proof. Appendix C writes up the model for this scenario (see Table 1). Applying the envelope theorem to $\left(13^{\prime}\right)$ and using (C.1), the effect on cost to market is

$$
\frac{\mathrm{d} m}{\mathrm{~d} T}=\frac{1}{p}\left(\frac{\mathrm{d} c}{\mathrm{~d} T}-1\right)=\frac{c-(1+T)}{(1+T) p}>0,
$$

where the numerator is the entrepreneur's risk premium over a safe wage. In zero profit equilibrium, the optimality condition for advice is $\left(16^{\prime}\right)$. Take the differential,

$$
\begin{aligned}
& \frac{\mathrm{d} a}{\mathrm{~d} T}=\frac{-1}{\pi^{\prime \prime}} \frac{\mathrm{d} \pi^{\prime}}{\mathrm{d} T}>0, \\
& \frac{\mathrm{d} \pi^{\prime}}{\mathrm{d} T}=\left(\frac{\mathrm{d} m}{\partial T}-\frac{\mathrm{d} c^{\prime}}{\mathrm{d} T}\right) p^{\prime}=\frac{c-(1+T)-p c^{\prime}}{(1+T) p} p^{\prime}>0 .
\end{aligned}
$$

Since $Q=m$ with free entry, (19) together with (24) and (25) establish the first part.

The private budget constraint combined with $\left(7^{\prime}\right)$ is $Y-T=C+Q D$. The government thus finances transfers in the amount of $T=v(Y-T)$. Differentiating at the untaxed position, a transfer $\mathrm{d} T$ requires a tax rate $\mathrm{d} v$ equal to $\mathrm{d} T=Y \mathrm{~d} v$. The marginal change in welfare is given by (21) except that $-\mathrm{d} t$ is replaced by $\mathrm{d} T$. Substitute $\mathrm{d} v / \mathrm{d} T=1 / Y$ and $\mathrm{d} m / \mathrm{d} T$ from (25) into (24). We get

$$
\left.\frac{\mathrm{d} V}{\mathrm{~d} T}\right|_{T=0}=\left(1-\frac{\mathrm{d} v}{\mathrm{~d} T}\right)-\frac{p E}{Y} \frac{\mathrm{d} Q}{\mathrm{~d} T}=\frac{(c-1) E}{Y}-\frac{(c-1) E}{Y}=0,
$$

where $Y-1=(c-1) E$ in the untaxed equilibrium with zero profits, see $\left(6^{\prime}\right)$.

When the government hands out uniform transfers, cost to market increases as in (24). The reasons are easily explained graphically in terms of Fig. 1. The 
increase in safe income $1+T$ results in a parallel shift of the participation constraint. ${ }^{25}$ Since the incentive constraint is steeper than the $45^{\circ}$ line, incentive compatibility dictates that the financier must raise the income in the good state relatively faster and the income in the bad state relatively slower than the safe income. This clearly increases the entrepreneur's risk which must be compensated by a higher risk premium and thereby inflates cost to market by the term $c-T=1+(c-1-T)$, see $\left(13^{\prime}\right)$. In the competitive equilibrium, higher cost to market results in higher project value, $Q=m$. Mainly for this reason, transfers magnify marginal benefits of advice, $p^{\prime}\left(m-c^{\prime}\right)$, while marginal costs remain the same. Consequently, transfers strengthen the incentives to provide active consulting services, see (25). Since higher cost to market erodes profits, VCs fund fewer projects until supply is sufficiently scarce to raise prices to a level that allows them to break even again. Entrepreneurship and industry output both decline, see (19a,b).

A proportional consumption tax combined with uniform transfers mimics a progressive tax that redistributes from high to low incomes. The government is able to provide further insurance of unconsolidated risk. This yields a net welfare gain that is proportional to the risk premium $c-1$ as in the first term of (26). However, such insurance weakens the entrepreneurs' incentives for effort. For this reason, financiers prefer to buy a smaller share at a lower price, exposing the entrepreneur to higher risk. Risk bearing must be compensated with a premium which is included in the cost to market and is finally passed on to consumers via a higher equilibrium price. The reduction in real income erodes welfare by exactly the same amount as government supplied insurance increases it.

To a large part, the public finance literature has discussed the benefits from social insurance by simply assuming the absence of private risk markets (see Varian (1980), Kanbur (1980) or Boadway et al. (1991), for example). In this paper, as in Buchholz and Konrad (2000), unconsolidated risk is an endogenous outcome of the optimal decisions of financiers who could otherwise costlessly provide full insurance. Risk bearing is surely an essential part of VC finance to retain incentives for high effort in the presence of moral hazard. It was not obvious a priori whether government should interfere with private risk sharing arrangements by further consolidating risk. In fact, recent literature has emphasized that lump-sum redistribution can shift incentive constraints and, thereby, lead to Pareto improvements although no simple policy rules have been derived from this insight (see Hoff (1994), Hoff and Lyon (1995) and Greenwald and Stiglitz (1986)). In the presence of costly state verification and partial private insurance, Black and de Meza (1997) find, for example, that subsidizing entry into the risky occupation is welfare improving. They emphasize that government can create collective insur-

\footnotetext{
${ }^{25}$ When discussing policy effects on cost to market, the envelope theorem implies that we do not need to consider the effect of advice on the success rate and, thus, on the slopes of the two constraints.
} 
ance more cheaply through its influence on equilibrium prices. ${ }^{26}$ The welfare effects from collective insurance in the presence of moral hazard may depend on how the associated shirking option is specified. ${ }^{27}$

\section{Conclusions}

Promoting entrepreneurship and business formation is widely recognized as an important policy objective. Among others, the OECD has recently concluded that entrepreneurial activity needs strengthening. ${ }^{28}$ The structure of taxes, the operation of financial markets, and the 'entrepreneurial climate' are important policy areas. This paper proposed a model of entrepreneurship and start-up investment that emphasizes risk-bearing on the part of entrepreneurs and its implications for occupational choice as well as the quality of outside finance. Even though financiers may, in principle, diversify project risk, some risk-bearing on the part of entrepreneurs is nevertheless required to contain moral hazard in the relation between VCs and entrepreneurs. Apart from financing, VCs also help with valuable business advice to enhance survival chances of their portfolio companies. We analyzed how tax policy might influence the propensity for entrepreneurship as well as the incentives for managerial support by financiers. We found that capital income (capital gains) taxation strengthens incentives for advice but reduces the number of entrepreneurs while a wage tax holds opposite incentives. A uniform income tax is neutral on all margins, distorting neither occupational choice nor incentives for advice. Progressive taxation, however, that uses a proportional (consumption based) income tax to pay for uniform per capita transfers, retards entrepreneurship and the expansion of innovative industries. Output and investment subsidies to start-up firms both stimulate entrepreneurial activity.

Among policy makers, it is often taken for granted that policy should actively promote start-up entrepreneurship and VC finance in innovative industries. Quite an impressive range of programs and subsidies are geared towards this goal. One could, of course, contemplate more traditional distortions such as imperfect competition among financiers, or learning and knowledge spillovers among them, to justify public policies on welfare theoretic grounds. Such arguments would not

\footnotetext{
${ }^{26}$ Buchholz and Konrad (2000) state a neutrality result in the same vein as Proposition 5 although their analysis is partial equilibrium and does not take into account general equilibrium price effects.

${ }^{27}$ The working paper version in Keuschnigg and Nielsen (2000) assumed that entrepreneurs, when shirking, could tacitly earn some outside income, instead of enjoying leisure or some other private benefit. While none of the other results were affected, we found a welfare gain from redistributive taxation. The specification adopted in the present paper is more in line with standard analysis of moral hazard and perhaps more realistic in describing behavior of start-up entrepreneurs.

${ }^{28} \mathrm{~A}$ recent OECD report on Austria, for example, includes a special feature on promoting entrepreneurship and employment, see OECD (1999).
} 
be specific to VC activity, however. In VC finance of highly innovative start-ups, the presence of informational asymmetries creates important incentive problems due to moral hazard and gives rise to agency costs that retard start-up investment. This does not imply, however, that government could improve upon the market allocation by means of taxes or subsidies since it is subject to the same informational problems. Private risk sharing and, indeed, the entire market allocation are socially optimal in our framework. Efficiency losses of taxes and transfers are therefore zero to the first order. Neither can the government raise welfare in providing social insurance via taxation. Because of moral hazard, private financiers intentionally abstain from offering complete insurance even though they could do so by means of diversification. The entrepreneur's risk sharing serves to preserve incentives for effort.

Future research should check the sensitivity of the policy conclusions by relaxing some of our assumptions on the nature of $\mathrm{VC}$ investing. It should prove worthwhile, for example, to emphasize less the importance of reputation and commitment of the $\mathrm{VC}$ to a promised level of advice, but to consider a situation of double moral hazard instead. ${ }^{29}$ With this assumption, the VC would choose advice only after the contract is specified, making advice dependent on her profit share. This implies that she would bear all the consulting costs but have to share with the entrepreneur the marginal profits from the extra advice. One expects advice to be inefficiently low then. However, as Schmidt (2000) argued, agents would then find it optimal to resort to more sophisticated financial instruments such as convertible securities, allowing them again to achieve the first best allocation in most circumstances! But then again, government could obviously not improve upon the market outcome, and our policy conclusions would largely remain the same.

\section{Acknowledgements}

EPRU is financed by a grant from the Danish National Research Foundation. We are indebted to Roger Gordon, Vesa Kanniainen, Kai Konrad and participants at seminars at the Universities of Helsinki, Tilburg and Saarbruecken, at the World Meeting of the Econometric Society in Seattle, and at a CEPR workshop at Tilburg University. We are grateful to the participants of the Transatlantic Public Economics Seminar 2000 in Gerzensee and especially to our discussants Thomas Gehrig and Kevin Hasset for stimulating comments. We particularly appreciate constructive comments by two anonymous referees.

\footnotetext{
${ }^{29}$ See, for example, Repullo and Suarez (1998), Schmidt (2000) and Kanniainen and Keuschnigg (2000). These papers uniformly assume risk neutrality. In contrast, we have stressed entrepreneurial risk bearing as an important determinant of start-up investment. Analyzing double moral hazard might prove difficult when agents are risk averse as in our model.
} 


\section{Appendix A}

\section{Cost of contract}

To prove Proposition 1, note that a higher survival chance affects the entrepreneur's profit share according to

$$
\frac{\mathrm{d} \theta}{\mathrm{d} p}=-\mu \frac{\theta}{p}<0, \quad \frac{\mathrm{d}^{2} \theta}{\mathrm{d} p^{2}}=\mu \frac{\theta}{p^{2}}\left(2+\frac{\theta \mu}{\theta+\beta}\right)>0,
$$

where the elasticity is defined as

$$
\begin{aligned}
& \mu \equiv \frac{p}{\theta} \frac{\partial \theta}{\partial p}=\frac{\theta+\beta}{\theta} \ln \left(\frac{\theta+\beta}{\beta}\right)>1, \\
& \frac{\mathrm{d} \mu}{\mathrm{d} p}=\frac{\beta \mu^{2}}{(\theta+p) p}-\frac{\mu}{p}=\frac{\mu}{p}\left(\frac{\beta \mu}{\theta+\beta}-1\right)
\end{aligned}
$$

The elasticity is positive and larger than unity. To see this, use (12) and write $(\theta+\beta) / \beta=1 / x$ where $x \equiv \delta^{-1 / p}<1$. Therefore, $(\theta+\beta) / \theta=1 /(1-x)$. With these transformations, $\mu>1$ is equivalent to $-\ln x>1-x$ which is fulfilled by concavity of the $\ln$-function. Note also that $x$ and therefore the elasticity $\mu$ are independent of all policy parameters.

With the capital gain $\beta$ constant as in (12), cost depends on $p$ as

$$
\begin{aligned}
& \text { (a) } c^{\prime}=\theta+p \frac{\partial \theta}{\partial p}=-\theta(\mu-1)<0, \\
& \text { (b) } c^{\prime \prime}=(1-\mu) \frac{\mathrm{d} \theta}{\mathrm{d} p}-\theta \frac{\mathrm{d} \mu}{\mathrm{d} p}=\frac{(\theta \mu)^{2}}{(\theta+\beta) p}>0 .
\end{aligned}
$$

\section{Appendix B}

\section{Managerial advice}

To obtain the policy effects on managerial advice as stated in Proposition 2, take the differential of $\pi^{\prime}=0$ in (16). An investment subsidy, for example, affects advice according to

$$
\frac{\mathrm{d} a}{\mathrm{~d} z}=-\frac{1}{\pi^{\prime \prime}} \frac{\partial \pi^{\prime}}{\partial z}
$$


By the second-order condition in (14), $\pi^{\prime \prime}<0$. The sign of the partial derivatives of (16) thus determines tax effects. Using (18), these are

$$
\begin{aligned}
\frac{\partial \pi^{\prime}}{\partial t} & =\left(\frac{\partial m}{\partial t}-\frac{\partial c^{\prime}}{\partial t}\right) p^{\prime}=-\frac{c / p-c^{\prime}}{1-t} p^{\prime}<0 \\
\frac{\partial \pi^{\prime}}{\partial \tau} & =1+\frac{\partial m}{\partial \tau} p^{\prime}=\frac{c / p-c^{\prime}}{m-c^{\prime}}>0 \\
\frac{\partial \pi^{\prime}}{\partial z} & =\frac{\partial m}{\partial z} p^{\prime}=-\frac{(1-\tau) K}{p} p^{\prime}<0
\end{aligned}
$$

In the first line, $\partial c^{\prime} / \partial t=-c^{\prime} /(1-t)$ by (A.3), (12) and the fact that the elasticity $\mu$ is independent of tax rates as mentioned following (A.3). The second line uses (18) and (16). Since $\theta$ and $c^{\prime}$ are independent of $z$ and $\sigma$, the other partials directly follow upon making use of (18). Finally, a uniform income tax with full loss offset satisfies $r=\tau=t$ and $z=0$ and, thus, leaves incentives for advice unaffected. Substituting (B.2) and using (16) again,

$$
\frac{\mathrm{d} \pi^{\prime}}{\mathrm{d} r}=\frac{\partial \pi^{\prime}}{\partial t}+\frac{\partial \pi^{\prime}}{\partial \tau}=0
$$

Alternatively, one may verify that all terms in (16) are proportional to a common tax factor $1-r$ which cancels. In particular, $\theta$ is proportional to $1-r$ as in (12).

\section{Appendix C}

\section{Lump-sum transfers}

Table 1 repeats those equations that change as a result of the scenario of Section 5. The primed equations must be compared with the basic model when all taxes and subsidies other than $T$ and $v$ are suppressed. All $N+L+E=1$ agents receive uniform per capita transfers $T$ which are part of disposable income in $\left(6^{\prime}\right)$. In particular, $c$ is the expected income of an entrepreneur, including transfers, and $c-T$ is the cost to the VC. With $\beta$ including $T$, the incentive constraint remains the same while the participation constraint must now list the entrepreneur's alternative income $1+T$ in $\left(11^{\prime}\right)$. A straightforward calculation shows how transfers affect the contract in $\left(12^{\prime}\right)$. With these results, we calculate the effect on expected income $c=p \theta+\beta$ as in Proposition 1,

$$
c^{\prime}=\theta(1-\mu)<0, \quad c^{\prime \prime}>0 ; \quad \frac{\mathrm{d} c}{\mathrm{~d} T}=\frac{c}{1+T}, \quad \frac{\mathrm{d} c^{\prime}}{\mathrm{d} T}=\frac{c^{\prime}}{1+T}<0 .
$$


The convexity of the cost function is proved exactly the same way as in Appendix A. We use $\left(12^{\prime}\right)$ of Table 1 to compute the effect of transfers on marginal cost $c^{\prime}$.

Table 1

Lump-sum transfers

$$
\begin{aligned}
& c=s p Q+b+T \text {, } \\
& \pi=p Q-a-K-(c-T), \\
& y^{F}=1+T+n \pi, \quad y^{L}=1+T, \\
& Y=1+T+(c-1-T+\pi) E, \\
& T=v(C+Q D) \text {, } \\
& \theta=s Q, \quad \beta=b+T, \\
& \left(P C^{\prime}\right): p \ln (\theta+\beta)+(1-p) \ln (\beta) \geq \ln (1+T) \text {, } \\
& \theta=\beta\left[\delta^{1 / p}-1\right], \quad \beta=(1+T) / \delta, \quad \mathrm{d} \theta / \mathrm{d} T \doteq \theta /(1+T), \\
& \pi=\max p(Q-m), \quad m \equiv[c(p, T)-T+a+K] / p, \\
& \pi^{\prime}={ }^{a}-p m^{\prime}=p^{\prime}\left(m-c^{\prime}\right)-1=0 .
\end{aligned}
$$

\section{References}

Barry, C.B., Muscarella, C.J., Peavy, III J.W., Vetsuypens, M.R., 1990. The role of venture capital in creation of public companies: evidence from the going public process. Journal of Financial Economics 27, 447-471.

Black, B.S., Gilson, R.J., 1998. Venture capital and the structure of capital markets: banks versus stock markets. Journal of Financial Economics 47, 243-277.

Black, J., de Meza, D., 1997. Everyone may benefit from subsidising entry to risky occupations. Journal of Public Economics 66, 409-424.

Boadway, R., Marchand, M., Pestiau, P., 1991. Optimal linear income taxation in models with occupational choice. Journal of Public Economics 46, 133-162.

Boadway, R., Marceau, N., Marchand, M., Vigneault, M., 1998. Entrepreneurship, asymmetric information, and unemployment. International Tax and Public Finance 5, 307-327.

Buchholz, W., Konrad, K.A., 2000. Risiko und Steuern. In: Andel, Norbert (Ed.), Probleme der Besteuerung III, Schriften des Vereins für Socialpolitik, N.F. Band 259/III. Duncker and Humblot, Berlin, pp. 63-139.

Cornelli, F., Yosha, O., 1997. Stage Financing and the Role of Convertible Debt, London School of Economics, mimeo.

DeMeza, D., Webb, D., 1987. Too much investment: a problem of asymmetric information. Quarterly Journal of Economics 102, 281-292.

DeMeza, D., Webb, D., 1988. Credit market efficiency and tax policy in the presence of screening costs. Journal of Public Economics 36, 1-22.

European Commission, 1999. Risk Capital Markets, a Key to Job Creation in Europe. From Fragmentation to Integration, Euro Papers No. 32, 1-36.

Gompers, P.A., 1995. Optimal investment, monitoring and the staging of venture capital. Journal of Finance 50, 1461-1489.

Gompers, P.A., Lerner, J., 1999. In: The Venture Capital Cycle. MIT Press, Cambridge, MA.

Gordon, R.H., 1998. Can high personal tax rates encourage entrepreneurial activity? IMF Staff Papers 45 (1), 49-80.

Greenwald, B.C., Stiglitz, J.E., 1986. Externalities in economies with imperfect information and incomplete markets. Quarterly Journal of Economics 101, 229-264. 
Hoff, K., 1994. The second theorem of the second best. Journal of Public Economics 54, 223-242.

Hoff, K., Lyon, A.B., 1995. Non-leaky buckets: optimal redistributive taxation and agency costs. Journal of Public Economics 58, 365-390.

Innes, R., 1991. Investment and government intervention in credit markets when there is asymmetric information. Journal of Public Economics 46, 347-381.

Kanbur, R.S., 1980. Risk-taking and taxation: an alternative perspective. Journal of Public Economics $15,163-184$.

Kanniainen, V., Keuschnigg, C., 2000. The Optimal Portfolio of Start-up Firms in Venture Capital Finance. CESifo WP No. 381.

Keuschnigg, C., Nielsen, S.B., 2000. Tax Policy, Venture Capital, and Entrepreneurship. CEPR DP 2626.

Kihlstrom, R.E., Laffont, J.-J., 1983. Taxation and risk-taking in general equilibrium models with free entry. Journal of Public Economics 21, 159-181.

Konrad, K.A., Richter, W.F., 1995. Capital income taxation and risk-spreading with adverse selection. Canadian Journal of Economics 28, 617-630.

Lerner, J., 1995. Venture capitalists and the oversight of private firms. Journal of Finance 50, 301-318.

Megginson, W.C., Weiss, K.A., 1991. Venture capital certification in initial public offerings. Journal of Finance 46, 879-893.

Mintz, J.M., 1981. Some additional results on investment, risk taking, and full loss offset corporate taxation with interest deductibility. Quarterly Journal of Economics 96, 631-642.

OECD, 1999. OECD Economic Surveys: Austria.

Peck, R.M., 1989. Taxation, risk, and returns to scale. Journal of Public Economics 40, 319-330.

Poterba, J.M., 1989a. Capital gains tax policy toward entrepreneurship. National Tax Journal 42, 375-389.

Poterba, J.M., 1989b. Venture capital and capital gains taxation. In: Summers, L.H. (Ed.). Tax Policy and the Economy, Vol. 3. MIT Press, Cambridge, pp. 47-67.

Repullo, R., Suarez, J., 1998. Venture Capital Finance: A Security Design Approach, CEMFI, Madrid, mimeo.

Sahlmann, W., 1990. The structure and governance of venture capital organizations. Journal of Financial Economics 27, 473-521.

Schmidt, K., 2000. Convertible Securities and Venture Capital Finance, University of Munich, mimeo. Varian, H.R., 1980. Redistributive taxation as social insurance. Journal of Public Economics 14, 49-68. 